\title{
Study on Cadmium Accumulation Characteristics of Grape Seedlings
}

\author{
Lijin Lin ${ }^{1, b}$, Yumei Tan ${ }^{2, b}$, Li Wang ${ }^{3, c}$, Fang Liü, ${ }^{4, d}$, and Ming'an Liao ${ }^{2, e^{*}}$ \\ ${ }^{1}$ Institute of Pomology and Olericulture, Sichuan Agricultural University, Chengdu, China \\ ${ }^{2}$ College of Horticulture, Sichuan Agricultural University, Chengdu, China \\ ${ }^{3}$ College of Animal Science and Technology, Sichuan Agricultural University, Chengdu, China \\ ${ }^{4}$ College of Life Science, Leshan Normal University, Leshan, China \\ allj800924@163.com, b2229809882@qq.com, wangli19800327@163.com, \\ diufang9028@163.com, elman@sicau.edu.cn
}

${ }^{*}$ Corresponding author. Lijin Lin, Yumei Tan and Li Wang contributed equally to this work.

\begin{abstract}
Keywords: Cadmium accumulation; Antioxidant enzyme activity; Grape seedlings
Abstract: The cadmium (Cd) accumulation characteristics of grape seedlings were investigated through a pot experiment. The results showed that with the increase of $\mathrm{Cd}$ concentrations, the root, stem, leaf and shoot biomasses of grape seedlings decreased, and the Cd contents in roots, stems, leaves and shoots of grape seedlings had the increase trend. The antioxidant enzyme (SOD and CAT) activity and soluble protein content of grape seedlings reduced when the dose of soil Cd was not more than $10 \mathrm{mg} / \mathrm{kg}$, and improved when the dose of soil $\mathrm{Cd}$ was higher than $10 \mathrm{mg} / \mathrm{kg}$. Therefore, $\mathrm{Cd}$ treatment could inhibit the growth of grape seedlings.
\end{abstract}

\section{Introduction}

With the improvement of people's living standards, the fruit has more and more proportion in the human diet [1]. Grape is one of the world's most important fruit tree species [2-3], and China's fresh grape planting area is the second of world for five consecutive years [4-5]. However, due to the long-term use of pesticide and fertilizer, the heavy metal accumulation in soil, and the heavy metal content in fruit excessive [6-7]. So, it is very important to study the Cd accumulation characteristics of grape. Under $\mathrm{Cd}$ stress, the $\mathrm{Cd}$ contents in different varieties of grape seedlings are significant different, and grafting could reduce the $\mathrm{Cd}$ content in fruits of grape [8]. There are few studies on the $\mathrm{Cd}$ accumulation characteristics of grape or other fruit trees [9-11]. The aim of this study was to study the $\mathrm{Cd}$ accumulation characteristics of grape seedlings, and provided a reference for grape production in Cd-contaminated soil areas.

\section{Materials and Methods}

Materials. The soil samples used in the experiment were collected from the Chengdu campus of Sichuan Agricultural University ( $\left.30^{\circ} 42^{\prime} \mathrm{N}, 103^{\circ} 51^{\prime} \mathrm{E}\right)$ in May 2016, which were uncontaminated by heavy metals. The grape seedlings were 'Jufeng' and 'Xiahei', which were the annual cutting seedlings with $25 \mathrm{~cm}$ height of young sprout.

Experimental Design. The soil samples were air-dried and passed through a 5-mm sieve. Four kilograms of the air-dried soil was weighed into each polyethylene pot (18 cm high, $21 \mathrm{~cm}$ in diameter). Cd was added to soils as $\mathrm{CdCl}_{2} \cdot 2.5 \mathrm{H}_{2} \mathrm{O}$ at $0,1,5,10,15$ and $20 \mathrm{mg} / \mathrm{kg}$ in April 2016, and the soil moisture was maintained at $80 \%$ of field capacity for one month. The uniform grape seedlings were transplanted into each pot in May 2016, and watered every day to keep the soil moisture content maintaining at $80 \%$ of field capacity. One pot planted one seedling, and each treatment was 6 replicates, respectively. After grape seedlings grew two months (July 2016), the whole plants were harvested. Then, the roots, stems, and leaves were washed with tap water, further washed with deionized water three times, and then dried at $80^{\circ} \mathrm{C}$ to constant weight for dry weight determination. The plant samples were finely ground and sieved through a $0.149-\mathrm{mm}$ mesh nylon sieve before digestion. The Cd 
concentrations were determined using an iCAP 6300 ICP spectrometer (Thermo Scientific, Waltham, MA, USA) [12]. The measured Cd values were checked against certified standard reference material (GBW-07602, bush branches and leaves) obtained from the China National Center for Standard Reference Materials.

Statistical Analyses. Statistical analyses were conducted using SPSS 13.0 statistical software (IBM, Chicago, IL, USA). Data were analyzed by one-way analysis of variance with least significant difference (LSD) at the $\mathrm{p}=0.05$ confidence level.

\section{Results and Discussion}

Biomass of Grape Seedlings. Under Cd stress, the biomass of grape seedlings decreased, but there were no obvious toxic symptoms in any treatments during the observation period (Table 1). With the increase of soil Cd concentrations, the root, stem, leaf and shoot biomasses of grape seedlings had the decreasing trend. At 1, 5, 10, 15 and $20 \mathrm{mg} / \mathrm{kg}$ soil Cd treatments, the root biomass of 'Jufeng' seedlings decreased by $8.73 \%(p>0.05), 9.61 \%(p>0.05), 20.96 \%(p<0.05), 29.69 \%(p<0.05)$, and 44.54\% ( $p<0.05)$, respectively, compared with the control, and the shoot biomass decreased by $1.32 \%(p>0.05), 7.02 \%(p>0.05), 18.41 \%(p<0.05), 32.98 \%(p<0.05)$ and $52.45 \%(p<0.05)$, respectively, compared with the control. For 'Xiahei' seedlings, the root biomass decreased by $1.07 \%$ $(p>0.05), 3.33 \%(p>0.05), 6.78 \%(p>0.05), 20.21 \%(p<0.05)$, and $27.82 \%(p<0.05)$, respectively, compared with the control, at $1,5,10,15$ and $20 \mathrm{mg} / \mathrm{kg}$ soil Cd treatments, and the shoot biomass decreased by $1.56 \%(p>0.05), 5.63 \%(p>0.05), 14.17 \%(p<0.05), 24.42 \%(p<0.05)$ and $37.99 \%(p<0.05)$, respectively, compared with the control. So, Cd stress inhibited the growth of grape seedlings.

Table 1 Biomass of grape seedlings

\begin{tabular}{|c|c|c|c|c|}
\hline Treatments & $\begin{array}{c}\text { Roots } \\
\text { (mg/plant) }\end{array}$ & $\begin{array}{c}\text { Stems } \\
\text { (mg/plant) }\end{array}$ & $\begin{array}{c}\text { Leaves } \\
(\mathrm{mg} / \mathrm{plant})\end{array}$ & $\begin{array}{c}\text { Shoots } \\
\text { (mg/plant) }\end{array}$ \\
\hline Jufeng & & & & \\
\hline 0 & $2.29 \pm 0.16 \mathrm{a}$ & $2.53 \pm 0.24 \mathrm{a}$ & $5.02 \pm 0.33 \mathrm{a}$ & $7.55 \pm 0.57 \mathrm{a}$ \\
\hline 1 & $2.09 \pm 0.17 \mathrm{ab}$ & $2.49 \pm 0.21 \mathrm{a}$ & $4.96 \pm 0.10 \mathrm{a}$ & $7.45 \pm 0.31 \mathrm{a}$ \\
\hline 5 & $2.07 \pm 0.13 \mathrm{ab}$ & $2.44 \pm 0.16 \mathrm{a}$ & $4.58 \pm 0.17 \mathrm{a}$ & $7.02 \pm 0.33 \mathrm{ab}$ \\
\hline 10 & $1.81 \pm 0.20 \mathrm{bc}$ & $2.26 \pm 0.13 \mathrm{ab}$ & $3.90 \pm 0.14 \mathrm{~b}$ & $6.16 \pm 0.27 \mathrm{~b}$ \\
\hline 15 & $1.61 \pm 0.17 \mathrm{~cd}$ & $1.75 \pm 0.30 \mathrm{~b}$ & $3.31 \pm 0.18 \mathrm{c}$ & $5.06 \pm 0.48 \mathrm{c}$ \\
\hline 20 & $1.27 \pm 0.18 \mathrm{~d}$ & $1.12 \pm 0.18 \mathrm{c}$ & $2.47 \pm 0.11 \mathrm{~d}$ & $3.59 \pm 0.30 \mathrm{~d}$ \\
\hline Xiahei & & & & \\
\hline 0 & $8.41 \pm 0.20 \mathrm{a}$ & $9.93 \pm 0.24 \mathrm{a}$ & $9.97 \pm 0.20 \mathrm{a}$ & $19.90 \pm 0.44 \mathrm{a}$ \\
\hline 1 & $8.32 \pm 0.31 \mathrm{a}$ & $9.78 \pm 0.17 \mathrm{a}$ & $9.81 \pm 0.27 \mathrm{a}$ & $19.59 \pm 0.45 \mathrm{a}$ \\
\hline 5 & $8.13 \pm 0.18 \mathrm{a}$ & $9.32 \pm 0.45 \mathrm{ab}$ & $9.46 \pm 0.76 \mathrm{ab}$ & $18.78 \pm 0.31 \mathrm{a}$ \\
\hline 10 & $7.84 \pm 0.23 \mathrm{a}$ & $8.46 \pm 0.48 \mathrm{~b}$ & $8.62 \pm 0.25 \mathrm{bc}$ & $17.08 \pm 0.74 \mathrm{~b}$ \\
\hline 15 & $6.71 \pm 0.27 \mathrm{~b}$ & $7.21 \pm 0.30 \mathrm{c}$ & $7.83 \pm 0.18 \mathrm{c}$ & $15.04 \pm 0.11 \mathrm{c}$ \\
\hline 20 & $6.07 \pm 0.34 \mathrm{c}$ & $6.04 \pm 0.37 \mathrm{~d}$ & $6.30 \pm 0.28 \mathrm{~d}$ & $12.34 \pm 0.65 \mathrm{~d}$ \\
\hline
\end{tabular}

Cd Content in Grape Seedlings. With the increase of soil Cd concentrations, the Cd contents in roots, stems, leaves and shoots of grape seedlings had the increase trend (Table 2). The order of Cd contents in roots, stems, leaves and shoots were ranked as roots $>$ stems $>$ shoots $>$ leaves. So, the $\mathrm{Cd}$ was main accumulated in the roots of grape seedligs. At 1, 5, 10, 15 and $20 \mathrm{mg} / \mathrm{kg}$ soil Cd treatments, the Cd contents in roots of 'Jufeng' seedlings were 2.59, 24.63, 65.43, 97.78 and 128.74 times of the control, and the Cd contents in shoots were 1.21, 1.27, 1.35, 1.43 and 1.52 times of the control. For 'Xiahei' seedlings, the Cd contents in roots were 1.81, 26.77, 41.12, 52.38 and 79.34 times of the control, and the Cd contents in shoots were 1.70, 1.79, 1.91, 2.03 and 2.22 times of the control. So, different varieties of grape had different $\mathrm{Cd}$ accumulation characterics, and 'Jufeng' seedlings 
accumulated more $\mathrm{Cd}$ in roots and shoots than that in 'Xiahei' seedlings. The roots of 'Jufeng' seedlings were more sensitive than 'Xiahei' seedlings to $\mathrm{Cd}$ stress.

Table 2 Cd content in grape seedlings

\begin{tabular}{|c|c|c|c|c|}
\hline Treatments & $\begin{array}{c}\text { Roots } \\
(\mathrm{mg} / \mathrm{kg})\end{array}$ & $\begin{array}{c}\text { Stems } \\
(\mathrm{mg} / \mathrm{kg})\end{array}$ & $\begin{array}{c}\text { Leaves } \\
(\mathrm{mg} / \mathrm{kg})\end{array}$ & $\begin{array}{c}\text { Shoots } \\
(\mathrm{mg} / \mathrm{kg})\end{array}$ \\
\hline Jufeng & & & & \\
\hline 0 & $0.737 \pm 0.027 \mathrm{e}$ & $0.169 \pm 0.008 \mathrm{e}$ & $0.162 \pm 0.011 \mathrm{~d}$ & $0.165 \pm 0.010 \mathrm{~d}$ \\
\hline 1 & $1.908 \pm 0.147 \mathrm{e}$ & $0.209 \pm 0.007 \mathrm{~d}$ & $0.196 \pm 0.006 \mathrm{c}$ & $0.200 \pm 0.006 \mathrm{c}$ \\
\hline 5 & $18.150 \pm 2.617 \mathrm{~d}$ & $0.214 \pm 0.008 \mathrm{~cd}$ & $0.206 \pm 0.008 \mathrm{bc}$ & $0.209 \pm 0.008 \mathrm{c}$ \\
\hline 10 & $48.222 \pm 2.514 \mathrm{c}$ & $0.228 \pm 0.002 \mathrm{bc}$ & $0.220 \pm 0.016 \mathrm{bc}$ & $0.223 \pm 0.011 \mathrm{bc}$ \\
\hline 15 & $72.062 \pm 4.155 \mathrm{~b}$ & $0.238 \pm 0.004 \mathrm{ab}$ & $0.235 \pm 0.013 \mathrm{ab}$ & $0.236 \pm 0.010 \mathrm{ab}$ \\
\hline 20 & $94.885 \pm 2.991 \mathrm{a}$ & $0.247 \pm 0.007 \mathrm{a}$ & $0.252 \pm 0.012 \mathrm{a}$ & $0.250 \pm 0.010 \mathrm{a}$ \\
\hline Xiahei & & & & \\
\hline 0 & $0.485 \pm 0.022 \mathrm{e}$ & $0.120 \pm 0.002 \mathrm{e}$ & $0.114 \pm 0.004 \mathrm{~d}$ & $0.117 \pm 0.003 \mathrm{e}$ \\
\hline 1 & $0.879 \pm 0.172 \mathrm{e}$ & $0.212 \pm 0.004 \mathrm{~d}$ & $0.186 \pm 0.005 \mathrm{c}$ & $0.199 \pm 0.004 \mathrm{~d}$ \\
\hline 5 & $12.985 \pm 1.152 \mathrm{~d}$ & $0.228 \pm 0.003 \mathrm{c}$ & $0.192 \pm 0.008 \mathrm{c}$ & $0.210 \pm 0.004 \mathrm{~cd}$ \\
\hline 10 & $19.941 \pm 2.205 \mathrm{c}$ & $0.236 \pm 0.006 \mathrm{bc}$ & $0.210 \pm 0.015 \mathrm{bc}$ & $0.223 \pm 0.011 \mathrm{bc}$ \\
\hline 15 & $25.403 \pm 2.259 \mathrm{~b}$ & $0.246 \pm 0.006 \mathrm{~b}$ & $0.231 \pm 0.013 \mathrm{ab}$ & $0.238 \pm 0.010 \mathrm{~b}$ \\
\hline 20 & $38.481 \pm 3.562 \mathrm{a}$ & $0.270 \pm 0.010 \mathrm{a}$ & $0.250 \pm 0.015 \mathrm{a}$ & $0.260 \pm 0.013 \mathrm{a}$ \\
\hline
\end{tabular}

Antioxidant Enzyme Activity of Grape Seedlings. Different from biomass, with the increase of soil Cd concentrations, the antioxidant enzyme (SOD and CAT) activity reduced when the dose of soil Cd was not more than $10 \mathrm{mg} / \mathrm{kg}$, and improved when the dose of soil Cd was higher than $10 \mathrm{mg} / \mathrm{kg}$ (Table 3). At 1, 5, 10, 15 and $20 \mathrm{mg} / \mathrm{kg}$ soil Cd treatments, the SOD activity of 'Jufeng' seedlings reduced by $30.19 \%(p<0.05), 32.54 \%$ ( $p<0.05), 50.47 \%(p<0.05), 32.93 \%(p<0.05)$, and $29.07 \%$ $(p<0.05)$, respectively, compared with the control. The CAT activity of 'Jufeng' seedlings reduced by $11.18 \%(p>0.05), 18.64 \%(p<0.05)$ and $33.83 \%(p<0.05)$ at 1,5 and $10 \mathrm{mg} / \mathrm{kg}$ soil Cd treatments, and improved by $9.08 \%(p>0.05)$ and $56.96 \%(p<0.05)$ at 15 and $20 \mathrm{mg} / \mathrm{kg}$ soil Cd treatments, respectively, compared with the control. For 'Xiahei' seedlings, the SOD activity reduced by $4.80 \%(p$ $<0.05), 6.05 \%(p<0.05)$ and $6.75 \%(p<0.05)$ at 1,5 and $10 \mathrm{mg} / \mathrm{kg}$ soil Cd treatments, and improved by $1.72 \%(p>0.05)$ and $7.82 \%(p<0.05)$ at 15 and $20 \mathrm{mg} / \mathrm{kg}$ soil Cd treatments, respectively, compared with the control. The CAT activity of 'Xiahei' seedlings reduced by $12.67 \%(p<0.05)$, $33.94 \%(p<0.05), 39.17 \%(p<0.05), 34.00 \%(p<0.05)$ and $7.20 \%(p<0.05)$ at $1,5,10,15$ and 20 $\mathrm{mg} / \mathrm{kg}$ soil Cd treatments, respectively, compared with the control. The soluble protein content of grape seedlings had the same trend as the antioxidant enzyme activity (Table 3 ). The soluble protein content of 'Jufeng' seedlings increased by $5.86 \%(p>0.05)$ and $21.38 \%(p>0.05)$ at 1 and $20 \mathrm{mg} / \mathrm{kg}$ soil Cd treatments, and decreased by $18.40 \%(p<0.05), 30.02 \%(p<0.05)$ and $39.41 \%(p<0.05)$ at 5,10 and $15 \mathrm{mg} / \mathrm{kg}$ soil Cd treatments, respectively, compared with the control. For 'Xiahei' seedlings, The soluble protein content increased by $13.57 \%(p<0.05), 10.26 \%(p<0.05), 27.75 \%(p<0.05)$ and $56.56 \%(p<0.05)$ at $1,5,15$ and $20 \mathrm{mg} / \mathrm{kg}$ soil Cd treatments, and decreased by $16.89 \%(p<0.05)$ at $10 \mathrm{mg} / \mathrm{kg}$ soil Cd treatments, respectively, compared with the control. The SOD specific activity of 'Jufeng' seedlings was ranked as $15 \mathrm{mg} / \mathrm{kg}>0 \mathrm{mg} / \mathrm{kg}>5 \mathrm{mg} / \mathrm{kg}>10 \mathrm{mg} / \mathrm{kg}>1 \mathrm{mg} / \mathrm{kg}>20 \mathrm{mg} / \mathrm{kg}$, and the order of SOD specific activity of 'Xiahei' seedlings was $10 \mathrm{mg} / \mathrm{kg}>0 \mathrm{mg} / \mathrm{kg}>5 \mathrm{mg} / \mathrm{kg}>1$ $\mathrm{mg} / \mathrm{kg}>15 \mathrm{mg} / \mathrm{kg}>20 \mathrm{mg} / \mathrm{kg}$.

\section{Conclusions}

Under Cd stress, with the increase of Cd concentrations, the root, stem, leaf and shoot biomass of grape seedlings decreased, and the $\mathrm{Cd}$ contents in roots, stems, leaves and shoots of grape seedlings had the increase trend. The antioxidant enzyme (SOD and CAT) activity and soluble protein content of 
grape seedlings reduced when the dose of soil Cd was not more than $10 \mathrm{mg} / \mathrm{kg}$, and improved when the dose of soil Cd was higher than $10 \mathrm{mg} / \mathrm{kg}$.

Table 3 Antioxidant enzyme activity of grape seedlings

\begin{tabular}{|c|c|c|c|c|}
\hline Treatments & $\begin{array}{c}\text { SOD activity } \\
(\mathrm{U} / \mathrm{g})\end{array}$ & $\begin{array}{c}\text { CAT activity } \\
(\mathrm{U} / \mathrm{g})\end{array}$ & $\begin{array}{c}\text { Soluble protein } \\
\text { content }(\mathrm{mg} / \mathrm{g})\end{array}$ & $\begin{array}{c}\text { SOD specific } \\
\text { activity (U/mg) }\end{array}$ \\
\hline Jufeng & & & & \\
\hline 0 & $249.88 \pm 5.67 \mathrm{a}$ & $28.97 \pm 1.41 \mathrm{bc}$ & $10.76 \pm 0.32 \mathrm{~b}$ & $23.22 \pm 1.21 \mathrm{a}$ \\
\hline 1 & $174.43 \pm 1.49 \mathrm{~b}$ & $25.73 \pm 0.41 \mathrm{~cd}$ & $11.39 \pm 0.29 \mathrm{~b}$ & $15.31 \pm 0.52 \mathrm{bc}$ \\
\hline 5 & $168.56 \pm 4.32 \mathrm{~b}$ & $23.57 \pm 1.18 \mathrm{~d}$ & $8.78 \pm 0.19 \mathrm{c}$ & $19.20 \pm 0.07 \mathrm{~b}$ \\
\hline 10 & $123.77 \pm 3.92 \mathrm{c}$ & $19.17 \pm 1.17 \mathrm{e}$ & $7.53 \pm 0.22 \mathrm{~d}$ & $16.44 \pm 1.02 \mathrm{bc}$ \\
\hline 15 & $167.59 \pm 3.32 \mathrm{~b}$ & $31.60 \pm 3.44 \mathrm{~b}$ & $6.52 \pm 0.98 \mathrm{~d}$ & $25.70 \pm 3.40 \mathrm{a}$ \\
\hline 20 & $177.25 \pm 3.42 \mathrm{~b}$ & $45.47 \pm 0.66 \mathrm{a}$ & $13.06 \pm 0.31 \mathrm{a}$ & $13.57 \pm 0.58 \mathrm{c}$ \\
\hline Xiahei & & & & \\
\hline 0 & $175.82 \pm 1.18 \mathrm{~b}$ & $33.62 \pm 1.57 \mathrm{a}$ & $6.63 \pm 0.43 \mathrm{~d}$ & $26.52 \pm 1.91 \mathrm{~b}$ \\
\hline 1 & $167.38 \pm 1.87 \mathrm{c}$ & $29.36 \pm 0.50 \mathrm{~b}$ & $7.53 \pm 0.35 \mathrm{c}$ & $22.23 \pm 1.27 \mathrm{c}$ \\
\hline 5 & $165.18 \pm 3.58 \mathrm{c}$ & $22.21 \pm 0.41 \mathrm{c}$ & $7.31 \pm 0.19 \mathrm{c}$ & $22.60 \pm 0.13 \mathrm{c}$ \\
\hline 10 & $163.95 \pm 0.21 \mathrm{c}$ & $20.45 \pm 0.46 \mathrm{c}$ & $5.51 \pm 0.12 \mathrm{e}$ & $29.75 \pm 0.61 \mathrm{a}$ \\
\hline 15 & $178.85 \pm 1.69 \mathrm{~b}$ & $22.19 \pm 1.32 \mathrm{c}$ & $8.47 \pm 0.09 \mathrm{~b}$ & $21.12 \pm 0.02 \mathrm{c}$ \\
\hline 20 & $189.57 \pm 0.63 \mathrm{a}$ & $31.20 \pm 0.60 \mathrm{~b}$ & $10.38 \pm 0.25 \mathrm{a}$ & $18.26 \pm 0.39 \mathrm{~d}$ \\
\hline
\end{tabular}

\section{Acknowledgements}

This work was financially supported by the Application Infrastructure Project of Science and Technology Department of Sichuan Province (2015JY0108; 2016JY0258).

\section{References}

[1] F.J. Peryea: Acta Horticulturae Vol. 564 (2001), p. 31.

[2] X.X. Wang and H. Deng: Sichuan Agriculture and Technology Vol. 45 (2014), p. 28.

[3] C.T. Wang: Chinese Horticulture AbstractsVol. 28 (2012), p. 159.

[4] L.Y. Zhang: Sino-Overseas Grapevine \& Wine Vol. 38 (2015), p. 64.

[5] S.H. Li, L.J. Wang, P.G. Fan and M.R. Yang: Heibei Forestry Science and Technology Vol. 32 (2004), p. 107.

[6] J.T. Li, J.W. Qiu, X.W. Wang, Y. Zhong, C.Y. Lan and W.S. Shu: Environment Pollution Vol. 143 (2006), p. 159.

[7] J.G. Feng, X. Tao and S.A. Sheng: Chinese Agricultural Science Bulletion Vol. 14 (1998), p. 29.

[8] X.H. Li, J.M. Tao, J.D. Chen, F. Hu and H.X. Li: Ecology and Environmental Sciences Vol. 19 (2010), p. 1082.

[9] L.Z. Zhang, K.G. Lu and H.Q. Yang: Acta Horticulturae Sinica Vol. 33 (2006), p. 111.

[10]J.G. Zhang, Q.K. Guo and C.P. Shi: Shanxi Fruits Vol. 5 (2004), p. 33.

[11]J. Shi, R.P. Hu, X.D. Chu, C.C. Li, J. Zhang and L.J. Lin: Shanxi Journal of Agricultural Sciences Vol. 62 (2016), p. 1.

[12] S.D. Bao: Soil Agricultural Chemistry Analysis (3rd eds., China Agriculture Press, Beijing, China, 2000). 